\title{
CORRECTIONS
}

\section{SURGICAL STIMULATION DOES NOT ENHANCE VENTILATORY CHEMOREFLEXES DURING ENFLURANE ANAESTHESIA IN MAN}

A.M. Lam, J.L. Clement and R.L. KNill.

Canadian Anaesthetists' Society Journal 27: 22-28 (January 1980)

Table I, page 25. In Group I, the $\mathrm{Pa}_{\mathrm{CO}_{2}}$ for anaesthesia alone should be $7.8 \pm 0.4 \mathrm{kPa}$ and the value for anaesthesia and surgery should be $7.4 \pm 1.1 \mathrm{kPa}$. These values differ significantly from each other $(\mathrm{p}<.05)$.

\section{REDUCTION OF POST-OPERATIVE VOMITING BY PREOPERATIVE ADMINISTRATION OF ORAL METOCLOPRAMIDE}

M.J. Diamond and M. Keeri-Szanto

Can. Anaes. Soc. Jour. 27: 36 (January 1980)

TABLE VI

SI ABDUNINAL HYSIERLCTOMILS

\begin{tabular}{lcc}
\hline & Vomited & Did not vomit \\
\hline Control & 13 & 13 \\
Treatment & 8 & 17
\end{tabular}

The reduction in postoperative vomiting in the treatment group does not reach statistical significance.

\section{NON-KETOTIC HYPERGLYCAEMIAS}

K.G. Belani and K.A. Sami

Can. Anaes. Soc. Jour. 27: 39 (January 1980)

The name of K.G. Belani, M.D., should be added to the signatures on this letter. 